Canadian University Music Review

Canadian University Music Review

Revue de musique des universités canadiennes

Jonathan P. Wainwright. Musical Patronage in

Seventeenth-Century England: Christopher, First Baron Hatton

(1605-1670). Aldershot, Hants: Scolar Press, 1997. 470 pp. ISBN

1-85928-278-4 (hardcover)

\title{
Kenneth McLeod
}

Volume 20, numéro 1, 1999

URI : https://id.erudit.org/iderudit/1015654ar

DOI : https://doi.org/10.7202/1015654ar

Aller au sommaire du numéro

\section{Éditeur(s)}

Canadian University Music Society / Société de musique des universités

canadiennes

ISSN

0710-0353 (imprimé)

2291-2436 (numérique)

Découvrir la revue

Citer ce compte rendu

McLeod, K. (1999). Compte rendu de [Jonathan P. Wainwright. Musical Patronage in Seventeenth-Century England: Christopher, First Baron Hatton (1605-1670). Aldershot, Hants: Scolar Press, 1997. 470 pp. ISBN 1-85928-278-4 (hardcover)]. Canadian University Music Review / Revue de musique des

universités canadiennes, 20(1), 121-125. https://doi.org/10.7202/1015654ar

All Rights Reserved (C Canadian University Music Society / Société de musique des universités canadiennes, 2000
Ce document est protégé par la loi sur le droit d'auteur. L’utilisation des services d'Érudit (y compris la reproduction) est assujettie à sa politique d'utilisation que vous pouvez consulter en ligne.

https://apropos.erudit.org/fr/usagers/politique-dutilisation/ 
and somewhat vague term (especially when taken out of context) that has been used of late is sonorous counterpoint.

One of the aspects of an analysis about which the author has been fastidious, and on which he has obviously spent considerable effort, is the identification of the mode of the work in question. This subject is, however, a very thorny one and the subject of numerous thoughtful studies. It is refreshing, therefore, to have Harley observe, when a work does not fit precisely into one or other of the customary modes, that Byrd might not have been "overly concerned with the niceties of modal theory" (p. 313), and, elsewhere, that a work is "in the key of G with two flats" (p. 322).

In a postscript (almost an afterthought) Harley addresses the reception history of Byrd's music. In the course of this review he states that "for most of this century Byrd has had a standing in English music equalled only by that of Purcell and Handel" (p. 369). Without justifying this assertion, he continues by asking the question, "What is it that gives Byrd this pre-eminence?" To his credit, Harley does attempt to grapple with this fundamental question. However, one would think that having written a book about a musician of such standing, the author could have come up with more substantive reasons for Byrd's status in the history of music than those that follow: the sheer quantity of it, the care he took to see that most of it was preserved, its competence, its invention, its originality, its unexpectedness, its sincerity, its depth, and its controlled but profoundly experienced emotional content. Even if one were to know what the author meant by the last seven items in this list (and he does not offer any explanation that I was able to find), their relationship to Byrd, as opposed to any other composer, is, for the most part, lacking in this volume, and, therein, lies its greatest fault.

The above criticism notwithstanding, Harley has written a book that has a place in the literature on William Byrd. The biographical portion is very thorough and is not likely to be superseded for some time to come. Conversely, the primary value of the works/chronological portion is likely to lie in the succinct overview of Byrd's music it provides and the further research and stylistic analysis it is likely to engender.

Eugene Casjen Cramer

Jonathan P. Wainwright. Musical Patronage in Seventeenth-Century England: Christopher, First Baron Hatton (1605-1670). Aldershot, Hants: Scolar Press, 1997. 470 pp. ISBN 1-85928-278-4 (hardcover).

Although much attention has been paid to the French influence on musical life at the Restoration Court, it was not the only, nor even the most important influence on English music of the seventeenth century. Underpinning much English "baroque" music, and indeed, even much French music from the period, are Italian methods. Jonathan Wainwright attempts to rectify the oversight of Italian influences by examining the operation and structure of seventeenth-century English musical patronage in the form of a case study of the activities of Christopher, First Baron Hatton (1605-70). Hatton owned one of 
the most substantial and important music collections in seventeenth-century England. The collection, much of which still survives today at Christ Church in Oxford, has important implications for understanding musical life during the Civil War at the Oxford Court (1642-46) and provides an excellent example of the extent of the dissemination and influence of Italian music in England during this period.

Patronage in the seventeenth century was, by its nature, relatively vague and undefined. Few musicians held permanent positions for musical purposes alone. They did not hold "jobs" per se, but rather they had relationships and ties to patrons with indefinite terms of responsibilities and remuneration. Impetus for a work often could come from either patron or musician; in many cases the musician offered his work as a gift to the patron and was rewarded with a gratuity, which often took the form of items or benefits other than money. A patron was frequently an enabler rather than an activator and thus, to a large degree, Wainwright often reveals Hatton to have only a loose involvement with the activities of his musicians and copyists. Of course patronage was of vital importance to English musicians in the seventeenth century. Musicians could not operate as independent individuals and were almost entirely reliant on institutional or noble patronage. The career advancement of musicians was dependent on the assistance of a well-placed and amenable patron or sponsor. One needs only to study the plethora of flattering dedications in musical productions of the period in order to apprehend the debt musicians owed to royal or noble patrons and to understand the important place of the patron-client relationship in the overall cultural milieu of the seventeenth century. The most significant patron was, of course, the monarch, and the subject of court patronage during this period has been the subject of a number of significant studies such as Arthur Ashbee's Records of English Court Music (Snodland, 1986-91), and Peter Holman's Four and Twenty Fiddlers: The Violin at the English Court, 1540-1690 (Oxford, 1993), among others. Wainwright, however, chooses not to delve into a great amount of detail regarding the general nature of patronage during this period, preferring instead to concentrate his efforts on the biographical details and conditions surrounding only the patronage of, and musical activities surrounding, Baron Hatton. As such, the book, though it will prove a well-researched and informative resource to some, is relatively limited in its scope and is less of a general survey of patronage in seventeenth-century England than implied in the title.

Wainwright divides his book into two large sections. The first section is devoted to the biography and context surrounding Hatton, his music collection, and his most important musicians and copyists. The second section, representing somewhat more than half of the book, presents a meticulous inventory of some of the most significant surviving manuscripts from the collection. This catalogue represents an important reference tool for those interested in English manuscripts and their dissemination during this period.

In the first section of his study Wainwright provides a detailed biography of Baron Hatton and his family. The Baron descended from a long line of music and art patrons. Orlando Gibbons, for example, spent some time at one of the 
Hatton residences around 1612 and is just one of several composers to have dedicated works to the family. Despite his prominent standing as a patron of the artistic community, Hatton had a relatively unspectacular political and court career. He was admitted to Gray's Inn in 1620 and was created a knight at Charles I's Coronation in February of 1626. He later became the Steward of several manors and became a Member of Parliament for Higham Ferrers in 1640. It was however with the onset of the Civil War in 1642 that Hatton's career reached its zenith. Hatton was among the first to join Charles I after the king moved the court to Oxford and his support for the royalist cause was recognized on 29 July 1643 when he was raised to the peerage as Baron Hatton of Kirby. Later that same year he was sworn as a privy councilor and soon became the Comptroller of the King's Household. Hatton played an active role in the politics of the Civil War and was a signatory to several important bills and undertook numerous diplomatic missions. In 1646, as Oxford surrendered to Sir Thomas Fairfax, Hatton joined the king and many other eminent royalists in exile in Paris and was only allowed to return to England in 1654. After the Restoration of Charles II, Hatton was appointed to the position of Governor of Guernsey. However his mismanagement of the position led to his quick removal, and he subsequently fell into disfavour with the king that precluded any further appointment to public office until his death in 1670 .

Throughout the peaks and valleys of his political career and the social upheavals of the Civil War and Restoration, Hatton continuously patronized a number of musicians and composers such as George Jeffreys, Stephen Bing, John Lilly, George Holmes, and Henry Cook. Music, however, was only one of Hatton's interests. His primary passions appear to have been the preservation of transcriptions of medieval records, and genealogical research into the families of English knights.

As Wainwright explains, Hatton's primary musical importance lies in his compilation of one of the largest music libraries of the day. Partly due to the troubled times in which he lived, Hatton's contribution to musical patronage has, until Wainwright's study, been largely overlooked. The nucleus of the collection, which survives at Christ Church, consists of twenty-five Venetian music prints and their copies, mostly of madrigal and motet collections, from the years 1624-38. Madrigals, motets, and other sacred and secular works by Italian composers such as Gesualdo, Monteverdi, Marenzio, and a host of other less well-known authors dominate the collection. The varied repertoire is marked by a preponderance of small-scale pieces that could be realized with a handful of singers and a continuo, suitable for performance at a wartime Court. Among the most obvious items to have survived is a set of three manuscript partbooks, Christ Church Mus. 432 and 612-13. These partbooks contain untitled fantasias and ayres for two bass viols and organ by Coprario, Jenkins, and Ward. In total Wainwright traces 202 items likely to be of Hatton provenance, 194 of which still reside at Christ Church and which represent up to 48 per cent of that library's pre-1670 music prints and one of the richest seventeenth-century music libraries yet identified. Though he offers little evidence 
in support of such a claim, Wainwright offers the possibility that the library of Christ Church, Oxford became a "de facto depository for Royalist music collections" during the Civil War (p. 186).

Wainwright provides a detailed examination of John Lilly and Stephen Bing, two of the Baron's copyists. Eschewing details of the day-to-day relationship of the Baron and his musicians, the author spends a great deal of time attempting to identify the hand of various scribes in order to attach Hatton provenance to various copies. In so doing he goes into significant detail in tracing the evolution of various clef styles, notation, paper, and rastrums. Wainwright's documentation is extremely fastidious and he provides an abundance of tables explaining the various details of manuscript contents, collations, and chronologies of various compilations, manuscripts, and copies. Wainwright particularly focuses on the work of Stephen Bing, who was eventually appointed Lay Vicar of Westminster Abbey, and who was responsible for copying a prodigious amount of material, not all connected with the Hatton collection. Among his most important copies is a set of eight books known as the "Bing-Ghostling Part Books." These books represent a vast compendium of English cathedral music composed between ca. 1570 and 1680 , including services and anthems from Tallis and Byrd through to Humfrey and Purcell, and are the sole music sources of several other anthems including two by Christopher Gibbons. In Wainwright's opinion, Bing's part books are important because "it is likely that many of his copies of works by composers such as Locke, Christopher Gibbons, Humfrey, Blow ... and Purcell derive directly from the composer's holographs or from first-generation copies" (p. 107). Indeed it is by virtue of Bing's manuscript copies that we are able to date a large number of Purcell's early compositions to before 1681 (the date of Bing's death), including the verse anthems Blessed Be the Lord My Strength and $O$ Lord Our Governor, among several others. Through the sheer chronological range of his activities, which lasted some fifty years, and his close associations with England's finest musicians and most influential patrons, Bing is revealed to have been one of the most important seventeenth-century English music copyists yet identified. In so doing, Wainwright constructs for the reader an invaluable picture of the inner workings of musical activity in England at this time.

One of the most interesting and significant chapters of Wainwright's book is devoted to the composer and organist George Jeffreys, Christopher Hatton's longest serving musician and secretary. Jeffreys was one of the first English composers to commit wholeheartedly to the latest Italian techniques, and as such his life and compositions have received a considerable amount of attention by scholars such as Peter le Huray and Peter Aston. Wainwright, however, fills a significant gap in our understanding of Jeffreys by detailing his compositions and copying activities in relation to the patronage of Hatton. It is with Jeffreys that Wainwright makes his strongest arguments regarding the influence and dissemination of Italian music in the early seventeenth century, for we know precisely what music was available to him (the Venetian printed music in the Hatton collection) and how and when it came into the country (bought by 
Hatton from the bookseller Robert Martin around 1638). Wainwright postulates that Jeffreys's exposure to Italian music in the Hatton collection, particularly the concertato motets written by contemporaries of Monteverdi such as Alessandro Grandi, led to his complete assimilation of the Italian seconda prattica style. This is particularly evident in the melodic shape and expressive use of dissonance found in his anthems, devotional songs, and motets. According to Wainwright, other Italianate features include the use "contrasting tripletime sections, contrasting homophonic sections in a pervading imitative texture, affective declamation, virtuoso solo writing, musical imagery, melodic and harmonic chromaticism, and unexpected harmonic progressions ..." (p. 158). Jeffreys wrote forty-eight concertato anthems and motets between 1638 and 1648 , and Wainwright even goes so far as to claim that Jeffreys "must be recognized as the main pioneer of Italianate sacred music in England" (p. 159). Unfortunately Jeffreys's musical career largely came to an end in 1646 with the fall of Oxford and his achievements have, until now, remained largely forgotten.

It is well known that English musicians and musical connoisseurs were actively interested in Italian music as soon as the early years of the sixteenth century. Italians appear in the lists of Henry VIII's musicians and from this point onwards Italian music was often imported and copied into English manuscripts. The influence of the Italian madrigal on English madrigalists in Elizabeth I's reign has been thoroughly researched by Einstein, Kerman, and others; however, the continued English interest in Italian music between the Elizabethan era and Purcell has been comparatively neglected. The manuscript copies made by Christopher Hatton II's musicians, Stephen Bing and George Jeffreys, offer a unique example of the dissemination of Italian music in England during the first half of the seventeenth century. The originality of Wainwright's contribution lies in his precise tracing and identification of which printed sources were used, to whom they belonged, and how and when they came to be in the country. Unfortunately Wainwright pays little attention to the influence of Italian music in the styles of Locke, Blow, and Purcell from later in the century. Though they lie somewhat outside the bounds of Wainwright's study, it would be an extremely useful endeavour to find answers to questions such as to what extent Italianate elements had become assimilated into the native English idiom by the Restoration period, and when and where do foreign styles end and personal styles begin. Nonetheless Wainwright provides a fascinating glimpse into the formation of one the most important English musical collections of the period. His detailed and extensive catalogue of the Hatton collection should prove an invaluable resource to scholars interested in the influence, availability, and dissemination of Italian music in pre-Restoration England.

Kenneth McLeod 